\title{
Awareness Level of Distance Learning Courses - A Study for Tamil Nadu Agricultural University
}

\author{
M. Malarkodi*, V.M. Indumadhi and S. Praveena
}

Department of ARM, Tamil Nadu Agricultural University, Coimbatore-641003, India

*Corresponding author

\section{Keywords}

Awareness, Chisquare, Distance learning, Education

Article Info

Accepted:

20 January 2018

Available Online:

10 February 2018

\section{A B S T R A C T}

Distance education had existed for more than a century, online learning was the current trend in distance education. Many universities in other countries were providing online degree at various levels such as associate degrees online, bachelor's degrees online, master's degree online, even Ph.D degree online. The study tried to assess the extent of awareness of students towards TNAU distance education programs. Considering the objectives of the study, sample respondents were categorized into Agricultural students and non agricultural students. The total sample size was 180 students consisting of 90 agricultural students and 90 non agricultural students. A well structured questionnaire was prepared to collect the required information. From the results, majority of the agricultural students were aware of TNAU distance education programme, whereas only 19 per cent of nonagricultural students were aware about the TNAU distance programme. The chi square analysis revealed that awareness about the TNAU distance education programme was statistically different between the agricultural and non agricultural students. The source of information about the TNAU distance education courses among the sample through friends and brochure.

\section{Introduction}

Distance education has been a natural outcome of the growing thirst for knowledge. It is especially relevant to the increasing educational needs of developing countries with their growing collaboration at regional, national and international levels. It is a means of acquiring knowledge and qualification without attending the college on a regular basis. "It is defined as institution-based, formal education where the learning group is separated, and where interactive telecommunication systems are used to connect learners, resources and instructors" (Simmonson, 2010). The distance education was institution based. The institution referred in this definition could be a traditional educational institution (school or college) or non-traditional institution (Businesses, company or corporations) that offer education to students at a distance. The second component of distance education is the concept of separation of the teacher and the student. Most often, separation is thought of in geographic terms: teachers are in one location and students in another. Asynchronous distance education means that 
instruction was offered and students access it at separate times, or any time it is convenient to them. Bridging the gap between the students and faculty is also a major objective of distance education system. The third component is the interactive telecommunication. Interaction can be synchronous or asynchronous, at the same time or at different times. The word "telecommunication system" implies electronic media such as television, telephone, and the internet, but this need not necessarily be limited to electronic media. Telecommunication is defined as "communicating at a distance." This definition includes communicating with the postal system, as in correspondence study and other non-electronic methods of communication. The final concept is that of connecting learners, resources, and instructors. Resources need to be subjected to instructional design procedures that organize them into learning experiences that promote learning. Distance learning is not possible without distant teaching.

Today, distance education is offered through a variety of formats. Radio, television, telecommunications, and especially the Internet have come to play an integral role in expanding the minds of students around the world. With the wide distribution and accessibility of computers, distance learning has become faster and more prevalent. Some solely online universities such as Phoenix University have hundreds of thousands of students and numerous institutions both small and large have sprung up in the past decade. Of course, traditional universities are not without online options as well, as it is estimated that almost $96 \%$ of them offer some kind of online coursework and that millions of students across the nation are enrolled.

The Tamil Nadu Agricultural University established during 1971 has trifold functions viz, teaching, research and extension education. The Agricultural College established during 1906 celebrated its centenary year during 2005. In commemoration of the centenary year of the Agricultural College and Research Institute Coimbatore the function of TNAU viz teaching, research and extension had been enlarged with additional function of Open and Distance Learning which was first of its kind in India, among State Agricultural Universities. The Directorate of Open and Distance Learning, one of the constituent units of the TNAU was started during April, 2005 by renaming the Directorate of Publications. This Directorate has started offering certificate courses through Distance Learning Mode for those aspiring for self employment. The main objective of the study is to identify the awareness level and source of information regarding TNAU distance education programme.

\section{Materials and Methods}

The present study was conducted in Coimbatore district which was purposively selected as it was considered as educational hub of Tamil Nadu. The study tried to assess the extent of awareness of students towards TNAU distance education programs, Considering the objectives of the study, sample respondents were categorized into two groups viz., Agricultural students and non agricultural students. From the vast number of colleges in Coimbatore, three arts colleges namely Bharathiar University, PSG College of Arts and Science and Kongunadu Arts and Science College were selected conveniently for sampling the non agricultural students and the Tamil Nadu Agricultural University was selected for sampling the agricultural students. The sample of 90 agricultural students and 90 non agricultural students were selected based on their willingness to participate in the survey. Thus, the total sample size was 180 students. A well structured questionnaire was prepared to collect the required information. 


\section{Results and Discussion}

The data collected from the sample respondents through survey method were analysed in this chapter. The details on the results obtained are presented and discussed.

\section{Personal profile of the respondents}

Gender is the most important form of social differentiation that may influence the distance learning process. The distribution of respondents according to the gender are given in the Table 1.

From the Table 1, it could be concluded that in case of agricultural students male respondents were more than female respondents whereas female respondents were more than male respondents among nonagricultural students. Similar results were found in Compton and Schock (2000). They reported that Colleges and Universities percentage of students during the last decade were women (Yukselturk and Bulut, 2009). The chi square analysis revealed that there were no significant differences in the gender distribution between agricultural and non agricultural students. It could also be concluded that the distribution of gender was not significantly different between agricultural and non agricultural students.

\section{Educational status}

Educational background of the respondents is another factor which plays a major role in influencing the student's attitude and interest in selecting their preferred courses through online. The data collected on the student's educational background were analysed and the results are presented in the Table 2.

From the Table 2, it could be concluded that among the agricultural students, majority of them were pursuing B.Tech (Bio informatics) while in the case of non-agricultural students, majority of the students were undergoing B.Sc., (Physics). Thilagam (2009) observed that there was a varied distribution and about 45 per cent of the students hailing from differential background which encompassed Agriculture, Arts, Science, Law and Technical grades. Mostly the students came from Agriculture background.

\section{Online learning experience of students}

Online learning is a formalized teaching with the help of electronic resources. Online learning experience is one of the important factors that are required to analyze whether respondents are aware of the new platform in distance education and also to find their interested field of study. Accordingly, the data regarding online learning experience of the sample students were collected and analysed. The results obtained are presented in the Table 3.

It was evident from the Table 3 , it could be concluded that non-agricultural students had more experience in online mode of distance education than agricultural students. It could also be concluded that the online experience was significantly different between the agricultural and non-agricultural students. This might be the reason that the online courses for general studies were more in number when compared to the agriculture related studies.

\section{Awareness of TNAU distance education programs}

Many universities and institutions were providing distance education programmes. Awareness is one of the important variable to determine whether the respondents are exposed to distance education programs offered by TNAU. An attempt was made to know the awareness about the TNAU distance education programmes among the agricultural and non-agricultural students within the study 
area. The data collected on awareness about the TNAU distance education programmes were analysed and the results are presented in Table 4.

From the Table 4, it could be concluded that agricultural students were more aware of TNAU distance education programmes when compared to non-agricultural students. Non agricultural students especially those who were from agricultural background had the awareness about the TNAU distance education courses. The chi square analysis revealed that awareness about the TNAU distance education programme was statistically different between the agricultural and non agricultural students. It could also be concluded that the awareness towards distance education programme was significantly different between the agricultural and non-agricultural students.

Table.1 Gender wise distribution of respondents

\begin{tabular}{|c|c|c|c|c|c|}
\hline \multirow[t]{2}{*}{ Sl.No } & \multirow[t]{2}{*}{ Category } & \multicolumn{2}{|c|}{ Agricultural students } & \multicolumn{2}{|c|}{ Non Agricultural students } \\
\hline & & Number & $\%$ & Number & $\%$ \\
\hline 1 & Male & 47 & 52.22 & 39 & 43.33 \\
\hline 2 & Female & 43 & 47.78 & 51 & 56.67 \\
\hline \multicolumn{2}{|r|}{ Total } & 90 & 100.00 & 90 & 100.00 \\
\hline \multicolumn{6}{|c|}{ Calculated $\chi^{2}$ value $=1.425 ;$ P value $=<0.2326 ; d(f)=p<0.05$} \\
\hline
\end{tabular}

Source: Calculated from primary data

Table.2 Educational Status of the respondents

$(n=180)$

\begin{tabular}{|r|l|c|c|l|c|c|}
\hline \multicolumn{4}{|c|}{ Sl. } & \multicolumn{4}{|c|}{ Agricultural students } & \multicolumn{3}{c|}{ Non Agricultural students } \\
\cline { 2 - 8 } No & \multicolumn{1}{|c|}{ Educational status } & Number & $\%$ & Educational status & Number & $\%$ \\
\hline 1. & B.Tech (AIT) & 25 & 27.78 & B.com & 11 & 12.22 \\
\hline 2. & BS (ABM) & 20 & 22.22 & B.Sc (mathematics) & 8 & 8.89 \\
\hline 3. & B.Tech (Bioinformatics) & 30 & 33.33 & B.Sc (microbiology) & 10 & 11.11 \\
\hline 4. & B.Sc (Horticulture) & 15 & 16.67 & B.Sc (Physics) & 23 & 25.56 \\
\hline & Total & $\mathbf{9 0}$ & $\mathbf{1 0 0}$ & & $\mathbf{9 0}$ & $\mathbf{1 0 0}$ \\
\hline
\end{tabular}

Source: Calculated from primary data

Table.3 Details on learning experience of students

\begin{tabular}{|c|c|c|c|c|c|}
\hline \multirow[t]{2}{*}{ Sl.No } & \multirow[t]{2}{*}{ Online Experience } & \multicolumn{2}{|c|}{ Agricultural students } & \multicolumn{2}{|c|}{ Non Agricultural students } \\
\hline & & Number & $\%$ & Number & $\%$ \\
\hline 1 & Prior Experience & 7 & 7.78 & 67 & 74.44 \\
\hline 2 & No experience & 83 & 92.22 & 23 & 25.56 \\
\hline & Total & 90 & 100.00 & 90 & 100.00 \\
\hline
\end{tabular}

Source: Calculated from primary data 
Table.4 Awareness about the TNAU distance education programmes

\begin{tabular}{|l|l|c|c|c|c|}
\hline Sl.No & \multirow{2}{*}{ Awareness } & \multicolumn{2}{|c|}{ Agricultural students } & \multicolumn{2}{|c|}{ Non agricultural students } \\
\cline { 3 - 6 } & & Number & $\mathbf{\%}$ & Number & $\%$ \\
\hline $\mathbf{1}$ & Aware & 89 & 98.89 & 17 & 18.89 \\
\hline $\mathbf{2}$ & Not aware & 1 & 1.11 & 73 & 81.11 \\
\hline Total & & $\mathbf{9 0}$ & $\mathbf{1 0 0 . 0 0}$ & $\mathbf{9 0}$ & $\mathbf{1 0 0 . 0 0}$ \\
\hline Calculated $\boldsymbol{\chi}^{\mathbf{2}}$ value= 118.96; & P value $=<\mathbf{0 . 0 0 0 0 1}$; significance $=\mathbf{p}<\mathbf{0 . 0 5}$ &
\end{tabular}

Source: Calculated from primary data

Table.5 Awareness about the various TNAU Distance education courses

\begin{tabular}{|l|l|c|c|}
\hline SI. No & Courses & \multicolumn{2}{|c|}{ Agricultural students } \\
\hline $\mathbf{1}$ & Mushroom Cultivation & 9 & Percentage \\
\hline $\mathbf{2}$ & MBA & 20 & 10.00 \\
\hline $\mathbf{3}$ & Coconut Cultivation & 8 & 22.22 \\
\hline $\mathbf{4}$ & Sugarcane Production & 20 & 8.89 \\
\hline $\mathbf{5}$ & Land Scaping & 8 & 22.22 \\
\hline $\mathbf{6}$ & Organic Farming & 9 & 8.89 \\
\hline $\mathbf{7}$ & Vermi Composting & 9 & 10.00 \\
\hline $\mathbf{8}$ & Bee Keeping & 7 & 10.00 \\
\hline & Total & $\mathbf{9 0}$ & 7.78 \\
\hline
\end{tabular}

Source: Calculated from primary data

Fig.1 Source of awareness about TNAU Distance education courses $(n=180)$

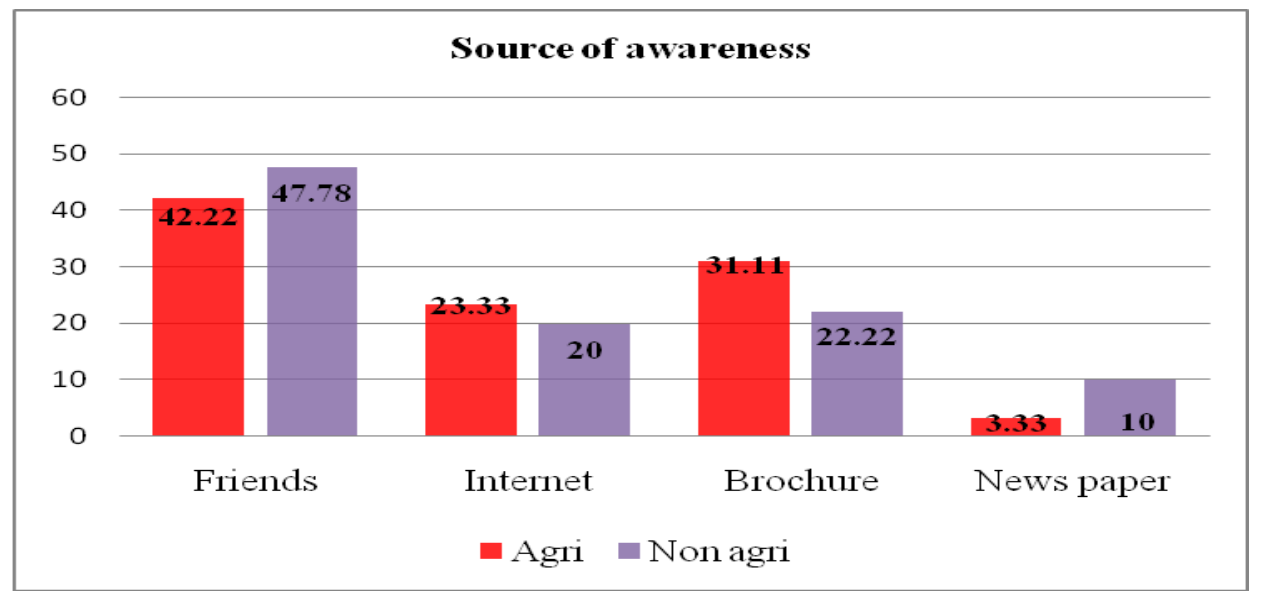

Awareness towards various courses offered by TNAU in Distance education programs

In order to study the awareness about the TNAU Distance education courses offered under each distance education programmes, the respondents were asked to recall and mention the TNAU distance education courses. It revealed that only agriculture students were aware about the various courses 
offered by TNAU in distance education programmes. Though a few percent of the non-agricultural students were aware about the existence and functioning of TNAU distance education programs, they were lacking in specific knowledge regarding the details of the courses offered under each distance education programmes of TNAU.

As a result, the awareness aspect of non agricultural students about the various courses offered by TANU couldn't be documented. The data collected on the awareness about the course specific knowledge on TNAU Distance education programme were analysed and are presented in the Table 5.

It could be observed that 22 per cent of the students were aware of MBA and Sugarcane Production Technology courses, 10 per cent were aware of Mushroom Production, Organic Farming and Vermi-composting courses, 9 per cent of the students were aware of Coconut Cultivation and Landscaping and remaining 8 per cent of the students were aware of Bee keeping.

\section{Source of information about the TNAU Distance education courses}

Source of information was one of the important factor to be noted. It would help the universities to understand, through which source majority of the students were receiving information about the TNAU distance education courses and to take better strategies so as to increase the awareness among students. The source of information about TNAU distance education courses were analysed and the results are presented in Figure 1.

From the Figure 1, it could be observed that 42 per cent of the agricultural student's source of information about the TNAU distance education courses was through friends, 31 per cent of them from brochure, 23 per cent of respondents from internet and remaining 3 percent were from news paper. In case of non agricultural students, 48 per cent of them got information about TNAU distance education courses from friends, 22 per cent from brochure, 20 per cent from internet and remaining 10 per cent were from news paper.

It could be concluded that friends were the major source of information for both agricultural and non agricultural students followed by brochure, internet and news paper.

The summary and conclusion is male respondents were more than female respondents among agricultural students whereas female respondents were more than male respondents among non-agricultural students. Non-agricultural students had more experience in online mode of distance education than agricultural students. Agricultural students were more aware of TNAU distance education programmes when compared to non-agricultural students. Major source of information for both agricultural and non agricultural students was friends followed by brochure, internet and news paper.

Based on the conclusions derived from the study, some suggestions have been made for the universities to take the following strategy Major source of information about distance education was through friends, brochure, internet and news paper hence, universities can intensify the awareness through print media and online advertisements so that more students would become aware of TNAU distance education.

\section{References}

Compton, M., and Schock, C. (2000). "The nontraditional Student in 
You". Women in Business, 52(4), 1416.

Simonson, Michael R. and Schlosser, L., "Distance education: Definition and glossary of terms." (2010). Fischler College of Education: Faculty Books and Book Chapters. 25. http://nsuworks.nova.edu/fse_facbook $\mathrm{s} / 25$

Venkaiah, V. and Salawu, I. O. (2009). "Student attrition in Dr. B. R. Ambedkar open University", Indian Journal of Open Learning, 18(3) pp.139-148.

Verma, A. K., Meena, H. R., Singh, Y. P., Chander, M., \& Narayan, R. (2012).
"Information seeking and sharing behaviour of the farmers-A case study of Uttar Pradesh State, India”. Journal of recent advances in agriculture, 1(2), 50-55.

Verma, S. R. (2014). "Impact of post graduate course on Sugarcane Technology offered through Open and Distance Learning Mode", Unpublished M.Sc. (Ag.) Thesis, AC \&RI, TNAU, Coimbatore.

Yukselturk, E. and Bulut, S. (2009). "Gender Differences in Self-Regulated Online Learning Environment", Educational Technology and Society, 12(3),12-22.

\section{How to cite this article:}

Malarkodi, M., V.M. Indumadhi and Praveena, S. 2018. Awareness Level of Distance Learning Courses - A Study for Tamil Nadu Agricultural University. Int.J.Curr.Microbiol.App.Sci. 7(02): 2155-2161. doi: https://doi.org/10.20546/ijcmas.2018.702.258 